US universities

\title{
Task force quests for financial wizardry
}

\section{Washington}

THE Congress's Science Policy Task Force was told last week that between $\$ 5,000$ million and $\$ 20,000$ million might be needed to bring US university research facilities up to acceptable modern standards, and that the existing partnership between universities, industry and government "may not be adequate" for the task. While the general sentiment has been heard before on Capitol Hill, this particular warning was surprising because it was uttered not by some university president making a cap-inhand appeal for a new laboratory, but an assistant director of the White House's Office of Science and Technology Policy, Dr Bernadine Healy.

In two days of hearings on "government and the research infrastructure", the task force heard a variety of prescriptions for improving universities' access to state-ofthe-art equipment. In Healy's view, both government and universities must take their share of the blame for the accumulated deficit of research hardware. Universities, she said, have often behaved like dependants of the government, "abdicating their responsibility for infrastructure and biding their time until federal facilities and programmes were resumed". The government, for its part, has "attempted not to invest in the research enterprise, but to procure packets of research results at the lowest possible prices"'.

The Science Policy Task Force, a bipartisan group established within the House of Representatives' Committee on Science and Technology, has been hearing from witnesses in government and academic life since mid-April. The hope is that a preliminary report will be completed by May next year, with a final version available the following October. Witnesses so far have fallen into two clearly defined camps: those who believe that the present system for provision of research facilities is working well, and those who feel that catastrophe is imminent.

The latter group argues that universities grew accustomed to 15 per cent annual increases in their operating research budgets during the heady 1970s, and even during the early years of the first Reagan presidency. As long as the hefty increases continued, universities were cushioned from the effects of the lack of investment in buildings and large items of equipment: most of the federal programmes specifically geared to improving research infrastructure had dried up in the early 1970s. Now that the days of 15 per cent annual increases are seemingly over, the price of years of underinvestment in the infrastructure will have to be paid.
Healy, speaking with the advantage of inside knowledge of the White House's soon-to-be-completed study of the universities chaired by David Packard, said that a multi-billion dollar programme might improve conditions, but that changes in attitudes would also be needed to put things to rights. Specific proposals include the following:

- the proportion of the $\$ 20,000$ million civilian research and development budget spent in universities should be increased above its present level of 30 per cent;

- unrestricted donations of equipment and contributions to renovations should be encouraged (presumably by favourable tax exemptions);

- amortization periods for both equipment and buildings assumed in federal grants should be reduced from their present unrealistically high levels (50 years and 15 years respectively) to something closer to reality (say, 20 years and 6-8 years); - and (as a strong hint) the government should stop trying to "micro-manage" equipment purchases and reduce the burden of excessive documentation.

The need for innovative financial approaches was echoed by Dale Corson, chairman of the government/university/ industry research round table sponsored by the National Academies of Science and Engineering. Corson asserted that obsolescence of research instruments is limiting productivity, and that in engineering, in particular, this state of affairs is increasingly driving away potential recruits into the field.

Corson argued that the problem has arisen largely because of the increased cost of research instruments; he proposed that more use should be made of shared facilities and that more facilities should be financed jointly with state governments. Besides exploring new ways of providing equity, the traditional form of financing for research facilities, universities should also look at new ways of debt financing. Corson asked for the removal of legal obstacles that, in essence, prevent the promise of federal grants from being used as collateral against loans.

Summing up in a virtuoso exhibition of Washington bureaucratese, Corson asked that these initiatives be brought together in a national programme that will "regularize the facilities appropriation process" and will "leverage federal funds to the maximum degree possible". Corson's proposal will doubtless be aired in July at a conference on academic research facilities sponsored by the government/university/ industry research round table and federal agencies.

Tim Beardsley
Growth hormone FDA ban on pituitary product Washington

FEARS that growth hormone extracted from human pituitary glands may spread the rare neurological condition known as Creutzfeldt-Jakob disease (CJD) have prompted the US Food and Drug Administration (FDA) to stop the use of all human pituitary products. Those most immediately affected are the 2,500 hypopituitary dwarfs in the United States, who depend on the hormone to maintain normal rates of growth; clinical research on other pituitary products has also been suspended. FDA is now under strong pressure to approve the general use of a recombinant human growth hormone product manufactured by Genentech Inc. that has been under FDA review for the past 18 months.

The two commercial companies that have now withdrawn their human-derived growth hormone products, KabiVitrum and Serano Laboratories, point out that the evidence against them is at best indirect. There have been three recent deaths attributed to CJD; among young men who received crude pituitary extracts as children; suspicions were aroused because the disease is normally found only in those over 40 . Only one diagnosis has been confirmed, however, and no autopsy was carried out on one of the suspected cases. In the other two cases, there are other complicating factors that could explain infection by a slow-acting virus such as that believed to cause CJD; one was a diabetic who received frequent insulin injections, for example.

The deaths occurred among patients who had been treated under the National Hormone and Pituitary Program of the National Institutes of Health (NIH). Since the programme started, the purification methods used have improved markedly, and all growth hormone manufactured since 1977 has been through a final stage of column chromatography using Sephadex. The commercial manufacturers, who also use column chromatography, point to a study by Professor A.G. Dickinson of the University of Edinburgh which indicated that virus deliberately introduced into pituitary tissue was not detectable after the column chromatography stage of purification.

One argument against a link between CJD and growth hormone is that the hormone is produced in batches that are used to treat several hundred children. Even if only one batch had been contaminated, therefore, many more than three cases would be expected. There are not known to be any living growth hormone recipients with CJD symptoms, and a recent survey of 300 recipients in Switzerland found no cases of CJD. 
Erol Caglarcan of Serano accuses FDA of using "unnecessary pressure" and says the Serano product, which has the trade name Asellacrin, will still be used outside the United States. Serano hopes in time to market a genetically engineered growth hormone being developed by Celltech in England, but that product is not yet at the stage of clinical trials. KabiVitrum's recombinant product, developed under licence from Genentech, is already in clinical trials in Europe: the company is correspondingly less concerned about FDA's action in banning human growth hormone.

The pressure on FDA to approve Genentech's recombinant product as quickly as is seemly arises because testing the pituitary samples for presence of the CJD infective agent has to be done by bioassay, using squirrel monkeys or chimpanzees. Besides being expensive, results of tests now being mounted by NIH will not be available for two years. In any case, negative results from such tests would not provide much reassurance, given that so little is known about the disease. If Genentech's product can be shown to be safe, FDA might be tempted to abandon pituitary-derived growth hormone permanently.

A decision to abandon pituitary products would, however, affect other substances besides growth hormone. Dr A.F. Parlow of the University of California at Los Angeles, who has supplied pituitary products to NIH since 1977 , is concerned that research into other pituitary hormones could be set back; clinical trials of prolactin and thyroid-stimulating hormone, for example, have had to be put on ice. Parlow believes that FDA will have to embark on a convincing demonstration that viruses can be effectively excluded by modern purification methods in order to prevent a complete halt in pituitary research.

Genentech first produced a recombinant growth hormone product several years ago, but - perhaps because of the ready availability of the human-derived product progress towards FDA approval has been slow. The Genentech hormone has an extra methionine residue tagged on that is not found in the natural substance, and in early clinical trials many patients developed antibodies to the product.

Last year, FDA asked Genentech to provide further safety data on a trial population to be monitored for a full year; that study is now under way but the data requested by FDA will not be complete until the start of 1986 at the earliest. Recently, however, FDA officials have been saying publicly that the Genentech product, which has now been improved, is likely to be approved within the next two or three months.

Genentech, for its part, is playing it cool, saying the decision is entirely up to FDA; a recombinant growth hormone without the extra methionine is also believed to be in the pipeline.

Tim Beardsley

French science budget

Fabius goes for

M. Hubert Curien, French minister for research and technology, at last has his figures.For the past few weeks he has been waiting to hear from the Prime Minister, M. Laurent Fabius, how much money there is in the kitty for French research for the next three years, to put some substance in his "three-year plan" for research - an instrument which parliament must vote on and which should give a new impetus to the political emphasis on science in France. The Prime Minister's answer is four per cent real growth per year in civil research and development spending to 1988 , excluding defence research spending.

And that is just the government side. There will also be increased incentives to industry to carry out research (a doubling of tax allowances on research and development budgets) which will give industry another FF 600-700 million (£60-70 million) a year to spend, so that overall it is estimated that French national research and development spending will rise over the next three years from $\mathbf{2 . 2 5}$ per cent of gross national product now to 2.6 per cent in 1988. At its nadir in 1979-80, this fraction had touched 1.8 per cent.

Thus the growth in French research spending should continue, provided there are no global budget "corrections" in future, corrections which rather reduced the true impact of the ambitious "law for science" introduced in 1982 by $M$. Curien's predecessor, M. Jean-Pierre Chevenement. But Chevènement also increased the number of jobs for scientists, and this trend is to continue. While British research councils have lost around a fifth of their posts since 1981, their French counterparts have gained something around 3 per cent a year. Curien's plan offers 1,400 new jobs for scientists over the next three years, less annually than last year's 1,000, but still a substantial figure.

So where are the French after all this attention to science? Doing fairly well, but could do better, particularly in industry, is the informed verdict in Paris.

Briefly, the tally is thought to be this. First, a reversal of the decline of support for French science in the 1970s. The decline was brought about initially by President Pompidou's massive indifference, and continued by successive administrations until Pierre Aigrain, science minister under President Giscard d'Estaing, reversed the trend. Second, M. Chevènement, under President Mitterrand, made science a political touchstone, and changed the whole French political mentality towards science, and of scientists towards industry. Third, the research councils - such as the Centre National de la Recherche Scientifique (CNRS) with its 10,000 scientists were accorded looser legal ties, which allowed them to make profitable associations with industry, set up affiliates and so @ 1985 Nature Publishing Group

\section{growth}

on. And fourth, science and technology were given weight, and budgets, in the regional administrations of France, which gave an opportunity for a more flexible response to local industrial and social needs. A fifth bonus, the new impetus given to universities to compete with one another for students and research cash, has come too late to yet have any real impact.

Failures, however, include a poor response from industry, too much centralization of decision-making and too little realistic assessment of the successes and failures of the policy.

There is hope, however, that Curien will be able to correct many of these failings. The new three-year plan, agreed at ministerial level but not yet voted upon, is one of his instruments. A practical man, Curien seems to be taking many of the right steps to put the rebirth of French science back on course.

Robert Walgate

\section{Australia's NDP in disarray \\ Canberra}

Australia's single-issue Nuclear Disarmament Party (NDP), whose 8,000 members include many former Labor Party supporters disaffected by the Hawke Labor government's decision in June last year to mine and export uranium, has lost its only parliamentary representative-elect, Ms Jo Vallentine, who resigned last week, announcing that she would set up a new antinuclear political party to be known as Peace and Nuclear Disarmament Action (PANDA).

This move follows NDP's first national conference in Melbourne last month in which Senator-elect Vallentine, former Labor Senator Ms Jean Melzer and narrowly-defeated NDP Senate candidate and rock singer, Mr Peter Garrett, staged a walkout, claiming that NDP was in danger of falling under the domination of entryist members of the Socialist Workers Party, a Marxist grouping of Trotskyite tendency. The conference was to have given some direction to NDP policy, because the party had only six months to organize before last December's half-Senate elections.

One of the chief reasons given by the breakaway group for leaving NDP was the party's "infiltration"' by people who were already members of other political parties: their proscription is likely to be a feature of membership of PANDA. The members of Ms Vallentine's West Australian branch of NDP were canvassed by a postal ballot that ended in a vote to cut all ties with the national body and form a separate party. Breakaway groups in most other states are holding similar ballots whose results will be known next month. Jeffrey Sellar 